Łukasz Danel*

\title{
SPECIAL RELATIONSHIP BETWEEN THE UNITED KINGDOM AND THE UNITED STATES OF AMERICA IN THE LIGHT OF BREXIT AND DONALD TRUMP'S VICTORY IN THE PRESIDENTIAL ELECTION
}

\section{Introduction}

The most famous speech by Winston Churchill ("Sinews of Peace Address") was delivered on 5 March 1946 in Fulton (Missouri, USA). It went down in history as the "Iron Curtain Speech"; sometimes, it is also called the symbolic beginning of the Cold War. However, on this occasion, the former prime minister of Great Britain used another term which, similarly to the Iron Curtain, became part of history of international relations and continues to be identified as a certain political term. This term was a "special relationship", and Churchill used it to describe the relations and connections between the countries of the British Commonwealth of Nations and the British Empire on the one side and, on the other, the United States of America.

In the modern British literature, the "special relationship" is most frequently defined as strong and close ties between the United Kingdom and the United States - ties based on the common language, cultural similarities and support for the same values resulting from the model of free-market economy and democracy relying on the idea of a representative government ${ }^{1}$. It is difficult to defy an impression that since the time of Churchill, this term has not really lost its significance - it is still used (and sometimes overused) very often today not only by British and American politicians, but also by political science specialists and political commentators to emphasise the special status of bilateral cooperation between these two countries. This cooperation has not always been agreeable and harmonious, yet it goes without doubt that the

\footnotetext{
* Department of Political Science, Cracow University of Economics.

1 A. Heywood, Essentials of UK Politics, Palgrave Macmillan, Basingstoke-New York 2011, p. 21.
} 
United Kingdom and the United States are close partners and allies as far as mutual political, economic, cultural, diplomatic relations are concerned, along with military cooperation and intelligence sharing. Such a partnership may be successfully dubbed strategic, primarily for the United Kingdom, which has been treating this alliance with absolute priority in its foreign and security policy.

The above-mentioned factors, such as the common language, culture (and, to a certain extent, also history), as well as the values embraced by both countries naturally facilitated and continue to assist maintaining this "special relationship." However, effective policy and diplomacy also includes personal relations between political leaders - in this specific case between the heads of the British governments and the presidents of the USA. Close ties between Churchill and Roosevelt, Thatcher and Reagan or Blair and Bush are only some examples that confirm the thesis that the "special relationship" also spans the dimension of political leadership and informal contacts and events that take place outside of the political arena.

2016 was a year of important political decisions both for the United Kingdom and for the United States. The British decided to leave the European Union in a national referendum, thereby putting an end to a period of quite close political and economic cooperation with the continental Europe. On the other hand, Americans elected Donald Trump as their president who, in his presidential campaign, announced the necessity of revising American foreign policy and verifying the list of key allies of the USA.

The author of the article attempts to provide an answer to the question on how these two events are likely to influence the "special relationship" between both countries and the shape of cooperation between Theresa May and Donald Trump. Even though both sides are declaring mutual support as of now, there are certain premises for putting forward a thesis about the first symptoms of a crisis - at least on the political and diplomatic arena. The first part of the article presents a historical outline of the "special relationship" with a particular attention given to the description of mutual ties and dependencies. On the other hand, the second part focuses on the current state of relations between the United Kingdom and the United States with a special emphasis on the potential problems that result from the events that have taken place on the British and American political scene in the recent months - the problems that can affect the "special relationship" in the coming years.

To address the research problem outlined above and to answer the research questions that have been put, both the historical analysis method and the content analysis method are used. Since the referendum on Brexit as well as Trump's victory in the USA took place relatively recently, not all of the research questions can be answered unequivocally or in a satisfactory way. For the same reason, the author is forced to relate to a limited number of source texts and must rely on different kinds 
of secondary sources like press articles or statements made by politicians. Nevertheless, the conducted analysis is supposed to cover all relevant aspects of mutual relations between the United Kingdom and the United States in order to fully address the research problem.

\section{Brief History of the "Special Relationship" and Its Significance for the Global Order}

Even though the term "special relationship" was coined in the $20^{\text {th }}$ century, it has to be strongly emphasised that the roots of the phenomenon as such are to be searched for in the $19^{\text {th }}$ century. The success of the American war of independence became a starting point for the construction of the American statehood (in a great degree in opposition to the British model) and emergence of American nationalism, which - due to well-known reasons - was primarily directed against the power of the British Empire. On account of numerous political barriers, the beginnings of the British and American relations were not easy. As justly noted by Ted B. Bromund, elimination of such barriers required fulfilment of three conditions ${ }^{2}$. First of all, the United Kingdom had to become a democratic state; hence, democratisation processes had to take place in it (in particular as far as the promulgation of voting rights was concerned), which brought the British state closer to the standards designated by the American constitution ${ }^{3}$. Secondly, Americans had to get rid of their Anglophobia which, mainly due to historical reasons, coupled with excessive suspiciousness towards Great Britain, which characterised the British and American relations for long decades and was one of the variables defining the American foreign policy. Thirdly, the United Kingdom had to accept the sad fact that it was - in contrast to the USA - a declining power, but still with global objectives and it would be best to strive to accomplish them in alliance with the United States. Therefore, it may be stated boldly that from this point of view, the "special relationship" is a natural consequence of certain historical processes which, in principle, had to come into being and, in an obvious manner, joined the United Kingdom and the United

2 T.R. Bromund, The Special Relationship: Anglo-U.S. Relations since 1776, "Oxford Research Encyclopaedia of American History" 2016, Oxford University Press USA, p. 2.

3 Voting right reforms were a breakthrough in this respect, in particular the ones from 1867 (Second Reform Act) and 1884 (Representation of the People Act), which, in a number of points, democratised the British voting law - obviously, as far as the conditions of the $19^{\text {th }}$ century are concerned. 
States of America by strong ties and partnership, which is manifested by close cooperation on various fields ${ }^{4}$.

In many respects the British and American alliance is therefore natural and non-accidental, as the two states have always been united by a number of factors conducive to the solidification of their political proximity (e.g. historical and ethnic ties, the common culture and language, common religion, economic dependencies, etc. $)^{5}$. However, throughout the $19^{\text {th }}$ century, as well as in the first half of the $20^{\text {th }}$ century, the relations were often tense and, at moments, even hostile. It is necessary to remember that the war of independence of the United States was waged against the British Empire which, for a long time (more or less until the middle of the $20^{\text {th }}$ century), was politically, economically and militarily stronger of the two partners.

Rapprochement was taking place gradually, especially in situations where it turned out that the United States and Great Britain have certain common geopolitical interests and they do not get in each other's way when pursuing them. A good example in this context is provided by the British support for the Monroe Doctrine of $1823^{6}$. The development disproportions between the industrialised, imperialist Great Britain and agrarian and anti-imperialist United States were also decreasing throughout the $19^{\text {th }}$ century, which was particularly important for the Americans, as it meant that they could be a more equal partner for the British. The period from the middle of the 1890s until the outbreak of WWII is often called the Great Rapprochement in the British and American relations, which meant closer dependencies in the political, economic and military area. This Great Rapprochement - in spite of the fact that it did not have any institutional foundations and was only based on regular cooperation and mutual recognition of similar interests - became the foundation for the subsequent "special relationship" .

The end of WWI was a time when the United States reverted to the policy of isolationism and neutrality (which may be exemplified by the decision on not joining the League of Nations, the demand to repay the war-time debt and not offering a security guarantee to its allies), which definitely did not facilitate development of relations with Great Britain. On the other hand, the Great Depression has revealed the weakness of American policy, but also became a breakthrough moment for the

4 T.R. Bromund, op.cit., pp. 2-4.

5 Cf.: A. Warchal, Zarys brytyjsko-amerykanskiego partnerstwa politycznego, [in:] Era Blaira i Browna. Wybrane problemy polityczne rzadów Partii Pracy w Zjednoczonym Królestwie 1997-2010, P. Biskup, F. Golembski, M. Kaczorowska (Eds.), Oficyna Wydawnicza ASPRA-JR, Warszawa 2010, pp. 187-197.

6 Getting rid of Spain and Portugal from the American continent was the beginning for constructing their own sphere of influence in the world for the Americans, whereas for the British - solidification of their global imperialism, as well as emergence of new trade perspectives.

7 T.R. Bromund, op.cit., p. 10. 
United States in the gradual take-over of the role of the main guardian of international trade and financial order from weakening Great Britain ${ }^{8}$.

The father of the term "special relationship" and, simultaneously, the politician who was fully aware of the fact that without the United States the allied forces would not have won WWII, was Winston Churchill. It turned out that he was completely right and the British and American cooperation during the war may be described as model. Churchill, whose mother was American, talked about the "special relationship" for the first time as the prime minister of the British government in a speech delivered in 1944, when he expressed: "deepest conviction that unless Britain and the United States are joined in a special relationship... another destructive war will come to pass". A year later, a similar statement was included in New York's "Times Herald"10. On the other hand, the above-mentioned speech in Fulton (Missouri) delivered on 5 March 1946, when Churchill, as the leader of the opposition Conservative Party, pointed out to the special bond between the United States on the one side and on the other, the states and nations of the British Commonwealth of Nations, went down in history: "Neither the sure prevention of war, nor the continuous rise of world organisation will be gained without what I have called the fraternal association of the English-speaking peoples... a special relationship between the British Commonwealth and Empire and the United States"11.

Churchill manifested his cordial approach to the United States and personally to President Roosevelt a number of times, also when he clearly pointed out that Great Britain was not interested in joining the first stage of the European integration which began after WWII ${ }^{12}$. In this way, he clearly showed the hierarchy of importance as far as Great Britain's foreign policy was concerned. The priority was the alliance with the United States, then the British Commonwealth of Nations and later everything that was meant to be created as part of the project of united Europe.

8 Ibidem, p. 11.

9 W. Lowther, G. Owen, Secret US memo for Congress seen by Mail on Sunday says Britain's 'special relationship' with America is over, "Daily Mail", 12 April 2015, http://www.dailymail.co.uk/news (retrieved: 27.04.2017).

10 The British politician quoted by the newspaper uttered the following words: "We should not abandon our special relationship with the United States and Canada about the atomic bomb and we should aid the United States to guard this weapon as a sacred trust for the maintenance of peace" - see: http://www.phrases. org.uk/meanings/special-relationship.html (retrieved: 27.04.2017).

$11 \mathrm{~W}$. Churchill, The Sinews of Peace. The text of the speech is available, for example, on the following website: https://www.winstonchurchill.org/resources/speeches/1946-1963-elder-statesman/the-sinews-of-peace (retrieved: 27.04.2017).

12 In this place, it is important to mention a famous statement by Churchill: If Britain must choose between Europe and the open sea, she must always choose the open sea", as well as words uttered to General Charles de Gaulle: "Every time I have to decide between you and Roosevelt, I will always choose Roosevelt" - see: https:// neweuropeans.net/article/604/revealing-deception-about-winston-churchill (retrieved: 27.04.2017). 
In the post-war period and in the face of the Cold War, the United States and Great Britain played a significant role in the institutionalisation of the broadly understood cooperation of the Western world in the form of various international organisations and agreements, among which it is necessary to mention the Organisation for Economic Cooperation and Development (OECD), the General Agreement on Tariffs and Trade (GATT) and, primarily, the North Atlantic Treaty Organisation (NATO). This also led to a certain asymmetry as part of the "special relationship", as more or less at that time the United States took on the role of the guardian of global order. Even if the alliance was sometimes called unilateral, Great Britain and the United States were united in aiming for implementation of certain common objectives and belief in international order relying on sovereign national states and such values as liberal democracy or the free market. No matter what is said about the mistakes that were made along the way, the world based on such values - common for Great Britain and the United States - has emerged victorious from the Cold War ${ }^{13}$.

After the collapse of the "Iron Curtain" and disintegration of the USSR, the United States remained the only global superpower and the British politicians continued to treat the "special relationship" as their priority. Therefore, often against the European or even British public opinion, Great Britain often supported military operations initiated by the United States (e.g. the First Gulf War between 1990 and 1991 or the intervention in Kosovo in 1999) or ones related to the fight with international terrorism (military operations in $A$ fghanistan and Iraq). It is commonly believed that the joint enemy - i.e. Islamic terrorism - was the factor that once again reinforced the British and American alliance. On the other hand, such military operations (in particular, the intervention in Iraq) cast a shadow on the "special relationship" as their meagre (and sometimes contrary to the desired ones) effects led to a number of misunderstandings along the line Washington - London and even destroyed the political career of the British Prime Minister - Tony Blair.

Subsequent British Prime Ministers - Gordon Brown and David Cameron - undertook activities aimed at sustaining the strategic partnership of Great Britain and the United States. However, they did not want to copy Blair's mistakes, so they treated this partnership in a more pragmatic manner, at the same time trying to move away from the uncritical outlook on the policy of the USA. Cameron straightforwardly warned about absolute loyalty towards the USA and the British obsession with the "special relationship"14.

13 T.R. Bromund, op.cit., pp. 15-18.

14 G. Gogowski, Znaczenie specjalnych stosunków ze Stanami Zjednoczonymi dla brytyjskiej polityki bezpieczeństwa po zakończeniu zimnej wojny, [in:] Nowe spojrzenia w naukach o polityce, W. Jakubowski, A. Krawczyk, J. Szczepański (Eds.), Wydawnictwo Uniwersytetu Warszawskiego, Warszawa 2012, vol. 2, p. 98. 
At the end of this part of the study, it is also worth mentioning that the political, economic and military alliance between Great Britain and the Unites States has always been solidified not only by the common values or cultural proximity, but also by personal contacts, and sometimes even friendships between the leaders of both states. In this context, it is necessary to mention, once again, the personal relations between Churchill and Roosevelt (it is said that between 1939 and 1945, the politicians exchanged approx. 1,700 letters); cordial ties also existed between Harold Macmillan and John F. Kennedy, Margaret Thatcher and Ronald Reagan or Tony Blair and George W. Bush. In the case of Thatcher and Reagan, it is often emphasised that they shared values as far as the vision of political and economic order in the world was concerned - both were ardent proponents of the free-market economy and both manifested their opposition to communism; what is more, both aimed for the final and victorious end of the Cold War rivalry with the Eastern Bloc ${ }^{15}$. As far as Blair and Bush are concerned, they were united not so much by ideology but - as mentioned earlier - the common enemy, i.e. Islamic terrorism. Even though the friendship with Bush cost Blair his political career, and the British media dubbed him the "poodle" of the American president, it goes without saying that he aimed for reinforcement of the "special relationship" and, in 2009, was rewarded for it with the Presidential Medal of Freedom by Bush ${ }^{16}$. On the other hand, it is easy to offer examples that mutual reluctance or a lack of close personal relationships between American presidents and British prime ministers hindered contacts and cooperation between these states. This is evidenced by cool relations between Dwight Eisenhower and Anthony Eden, Lyndon Johnson and Harold Wilson or Bill Clinton and John Major.

\section{The "Special Relationship" in the Light of 2016 Political Events}

Generally speaking, the current status of the "special relationship" between the United States and Great Britain is a vast area. It is necessary to look at it in the political and economic dimension, but also in the context of military cooperation and intelligence sharing, as well as international security and hazards that the present-day world is facing. Such a detailed analysis goes beyond the framework of this study;

\footnotetext{
15 Ibidem, p. 88.

16 T. John, Theresa May and Donald Trump and 5 Other 'Special Relationships', “Time”, 26 January 2017, http://amp.timeinc.net/time (retrieved: 22.04.2017).
} 
instead, the author has decided to focus on evaluating the described phenomenon on the basis of the political events which took place in 2016 in the United States and in the United Kingdom.

First of all, the British decided (in June 2016) in a national referendum that after over 40 years of the membership in the European Communities, their country should go its own way and leave the European Union. As part of direct political effects, this led to the resignation of David Cameron from the function of the prime minister of the British government and his replacement by Theresa May. Even though May - similarly to Cameron - was against Brexit, she is now forced to lead her country through a wearisome and complicated operation of breaking the hitherto ties with the Union and to negotiate with the leaders of the European states a new agreement on cooperation, whose shape - as of this moment - seems very hazy and unspecific. In the background of these events, a question about relations with the United States is looming, as the United States was intent on the political and economic unity on the European continent in the past, treating the European Union as its important partner. However, it turned out that a few months later (in November), Donald Trump became the $45^{\text {th }}$ president of the USA - a politician who not only openly supported Brexit and criticised NATO, but also announced in his presidential campaign that the United States would revert to the policy of isolationism. In this context, it is necessary to ask more research questions - how all of this will influence the "special relationship" and what type of relations will emerge between Theresa May and Donald Trump.

Only a year has passed since the election of Trump as president of the United States, but everything indicates that at least until 2020 he will be responsible for the foreign policy of the US $\Lambda$ and relations with heads of other states, as well as Theresa May, the prime minister of the British government. In spite of the fact that many statements of the US president have encountered criticism of the British political elites, Prime Minister May has signalled a number of times that for Great Britain, the "special relationship" is still a vital element of foreign and security policy. In a statement issued after the announcement of the results of the US presidential elections, May clearly hinted that the United States and Great Britain have an "enduring and special relationship based on the values of freedom, democracy and enterprise", adding that they will remain "strong and close partners on trade, security and defence", as well as that she expected to cooperate with Trump "building on these ties to ensure the security and prosperity of our nations in the years ahead"17. This announcement

17 What does Trump victory mean for UK-US 'special relationship'?, Reuters, 9 November 2016, https:// www.rt.com/document (retrieved: 28.04.2017). 
was interpreted as a willingness to warm the "special relationship" strained by the events of several years in the past and also, to a certain degree, the words of May's predecessor, David Cameron, who assessed Trump's proposal made during the presidential campaign in the USA to introduce a temporary ban on Muslims entering the USA as "divisive, stupid and wrong"

Theresa May, similarly to Margaret Thatcher in the past, was the first foreign leader to pay the newly-elected president of the USA a state visit. It took place on 27 January 2017, so already after the official inauguration of Trump as president. Even though both leaders manifested their mutual support and understanding, the above-mentioned political circumstances in which the visit took place offer grounds for an attempt at presenting a more detailed analysis of the present-day status of "special relationship" between the United States and Great Britain.

Quite paradoxically, Great Britain's departure from the European Union may lead to the tightening of the relations with the United States, as Trump perceives European integration and the role of Great Britain in this common European political and economic project in a manner completely different than his predecessors. As it has already been mentioned, after WWII the British rejected Shuman's Plan and, at their own request, did not sign the Treaty of Paris establishing the European Coal and Steel Community, at that time putting the "special relationship" with the United States and the interests of the Commonwealth of Nations in the first place ${ }^{19}$. In spite of it, American presidents were intent on Great Britain's joining the integration processes in Europe and Kennedy even said directly that the maintenance of the "special relationship" will not be possible if Great Britain fails to join the European Economic Community $(\mathrm{EEC})^{20}$. It was in Washington's best interest for London to play an important role in the European policy, as on account of the similar outlook on a number of political and economic issues, the Unites States was definitely closer to Great Britain than to any other European state. Therefore, it seemed that the potential exit of Great Britain from the European Union would lead to the cooling off of its relations with the United States. In any case, this is what the previous president, Barack Obama, hinted at when visiting London shortly before the Brexit referendum, encouraging Brits to stay in the Union and warning that otherwise they would put themselves "at

18 David Cameron stands by attack on Donald Trump over Muslim 'ban', BBC News, 16 May 2016, http:// www.bbc.com/news (retrieved: 28.04.2017).

19 Ł. Danel, Demokracja brytyjska w obliczu Brexitu i ewentualnej dekompozycji Zjednoczonego Królestwa, [in:] Demokracja współczesna - wymiar polski i międzynarodowy, J. Kornaś, Ł. Danel (Eds.), Wydawnictwo Adam Marszałek, Toruń 2016, p. 404.

20 A. Sybilla Bidwell, Dzieje Wielkiej Brytanii w XX wieku. Od światowego imperium do „matego państwa” na obrzeżach Europy, Wydawnictwo Szkoły Wyższej Psychologii Społecznej "Academica", Warszawa 2008, p. 189. 
the back of the queue in any trade deal with the US ${ }^{\prime 21}$. However, it turned out that the presidential election in the USA was won by a Brexit proponent who - similarly to numerous British politicians - believes that in the global dimension Great Britain will be stronger outside of the European Union than if it decided to stay in the Union. And definitely, Brexit will not aggravate British relations with the USA now.

Nevertheless, putting the issue of the "special relationship" aside, Trump's approach may completely redefine Transatlantic relations, as from the perspective of the USA, close cooperation of the European countries has always been a value in itself and a united Europe was treated as a serious partner in "promoting its vision of the world based on international institutions, free trade, globalisation, and primarily liberal and democratic values"22. Meanwhile, Trump not only praises Brexit, but also seems to encourage other member states of the EU to take similar steps by suggesting that the Union primarily serves the interest of Germany ${ }^{23}$. Such an approach may greatly influence further cooperation between the United States and the European continent.

However, turning back to Great Britain - the question about the condition and further fate of the "special relationship" is definitely more complex, mainly due to the fact that the US president does not always speak consistently and clearly about various issues of key importance for the British. Already in his presidential campaign Trump strongly emphasised economic protectionism and return to isolationism ${ }^{24}$, which may also prove to be an obstacle in the relations with Brits, who believe in the free market and free trade.

After the EU membership referendum, but yet before Trump was elected president it seemed to British politicians that Brexit would lead to closer economic cooperation between the United Kingdom and Great Britain. All the more so, because for the United States Great Britain is Europe's most important trading partner and in terms of export the British market constitutes the largest European market for American goods.

Britain's willingness to leave not only the European common market (which in turn is the largest market for British exports), but even the EU customs union means that it will need to find a new place in the global economy. Naturally, this

21 A. Asthana, R. Mason, Barack Obama: Brexit would put UK 'back of the queue' for trade talks, "The Guardian", 22 April 2016, https://www.theguardian.com (retrieved: 28.04.2017).

22 P. Buras, Przygotujcie się na nową Europę, Fundacja im. S. Batorego, Warszawa 2017, p. 6.

23 Ibidem.

24 This is for example testified by the necessity of reforming the North American Free Trade Agreement (NAFTA) or potentially even complete US withdrawal from this Agreement. For a more detailed analysis of Trump's foreign policy see for example: K. Larres, Donald Trump and America's Grand Strategy: U.S. foreign policy towards Europe, Russia and China, "Global Policy", May 2017, http://www.globalpolicyjournal.com/ (retrieved: 12.10.2017). 
should lead to tightening of the Atlantic alliance and reaping the benefits of the various types of trade agreements the US is - or is about to become - a party to. In this context, the foreign policy of the Barack Obama administration and his famous "pivot to Asia" were for Great Britain a very interesting alternative to European integration. The central point of this pivot was the Trans-Pacific Partnership (TPP), which was intended to halt China's economic expansion in the Pacific Rim and reaffirm the global domination of the United States. Since 2013, the US has also been conducting negotiations on the Transatlantic Trade and Investment Partnership (TTIP), the main goal of which is to establish a free trade area between the United States and the European Union (consisting of 28 member states). Brexit does not seem to have denied the possibility of Great Britain joining the agreement, even after it would eventually leave the EU. Such a position was presented by the United States Secretary of State - John Kerry, who even expressed the hope that for those British people who voted to leave the EU because they felt disappointed with globalisation, the entry into force of the TTIP agreement would mean that Great Britain will get those benefits of globalisation ${ }^{25}$.

Nevertheless, Trump's victory made this plan too complicated. His first decisions showed that his declarations of a return to the policy of isolation will be gradually implemented and put into practice. This is evidenced by the definite withdrawal of the US from the Trans-Pacific Partnership, which happened on 23 January 2017 when Trump signed a relevant executive order. $\Lambda t$ this moment, the fate of the TTIP is unknown. Negotiations on this agreement have been postponed indefinitely after the US elections, but both sides are ready to resume their talks. One possible scenario for the future is to say that the absence of a definitive withdrawal from the TTIP by the United States is to be interpreted as making further negotiations in the matter dependent on the outcome of the talks on a US-UK trade agreement.

What is sure - Obama's threats of "the end of the queue" were outdated as soon as the results of the Brexit referendum were made official. At the aforementioned meeting in Washington, Theresa May and Donald Trump unanimously announced a new trade agreement between the United States and the post-Brexit Great Britain. It is of course necessary to remember that such an agreement will only be signed after Great Britain has officially left the European Union, which will probably not be earlier than in a few years' time. Nevertheless, talks and preliminary negotiations on a future agreement are underway, which is not denied by either the Americans or the British. From an American perspective Brexit does not change much - Britain

25 P. Wintour, US seeking bilateral trade deal with UK to press EU on TTIP, "The Guardian", 20 July 2016, https://www.theguardian.com (retrieved: 15.11.2017). 
remains a key economic partner and the "special relationship" should not be affected. Surely, a much more uncertain future is drawn up today in the United Kingdom, for which Brexit may either turn out to be an economic catastrophe as well as an opportunity for a more dynamic development and also increasing its role in global politics and the new world order ${ }^{26}$. Everything depends on the conditions on which Great Britain will leave the Union and the terms of the agreement defining the future relations between both parties. Theoretically, there is even a scenario that Britain fails to reach any deal with the EU (so called "dirty Brexil"). That would mean the implementation of a "WTO option" that involves trading solely under the rules set by the World Trade Organisation, which Britain is a member of, however, at least for the moment, operating not independently but through the EU. And although for some representatives of the British Cabinet this perspective may look tempting, today it seems to be the worst option possible - also for the American side. Basically, every scenario is a challenge for Great Britain because anyway it will have to bear significant short and mid-term costs rewiring its economy ${ }^{27}$.

Another potential bone of contention between the US federal government and the British cabinet is the military cooperation within NATO, even though President Trump has gone through a quite significant evolution in his views. Some time ago, he called the Alliance "obsolete", but today he seems to be convinced of the necessity of reinforcing it, only criticising the fact that not all the member states fulfil their financial obligations towards NATO by devoting $2 \%$ of their GDP on defence. For Great Britain, NATO is one of the pillars of the contemporary global order and the global security system. A lot of controversies have also accompanied Trump's statements about Russian President Vladimir Putin and the possibility of working with him against the Islamic State. On the other hand, May clearly does not have a good opinion about Russia's participation in the Syrian conflict and she is for sustaining sanctions imposed on Russia for destabilising eastern Ukraine. Trump is also strongly criticised for his immigration policy, which he started (with varying effects) to implement after taking the presidential office. May's opinions on immigration are probably not as extreme as Trump's, but some of her statements testify to the fact that in this respect, she is closer to the US president than to Chancellor Angela Merkel. In any

${ }^{26}$ For a more detailed analysis of the economic consequences of Brexit see for example: The economic consequences of leaving the EU. The final report of the CER commission on Brexit 2016, Centre for European Reform, April 2016, http://www.cer.eu/sites/default/files/smc2016_26april2016.pdf (ret rieved: 15.10.2017) or Out and down. Mapping the impact of Brexit, The Economist Intelligence Unit, http://www.transatlanticbusiness.org/wp-content/uploads/2016/09/Out-and-Down-Mapping-the-Impact-of-Brexit-The-Economist-Intelligence-Unit.pdf (retrieved: 15.10.2017).

27 P.J. Crowley, How Brexit will affect US-UK relations, BBC News, 26 June 2016, http://www.bbc.com/ news/ (retrieved: 20.11.2017). 
case, the opposition to the free movement of people has been one of the driving forces of Brexit, hence it seems that in reference to the immigration policy, Trump may count on the understanding of the British Prime Minister ${ }^{28}$.

\section{Conclusion}

In spite of the fact that the British and American alliance has survived a number of trials and tribulations and is considered exceptionally durable and consistent, in the recent years numerous commentators of political life have been paying attention to the fact that it has been losing its significance - primarily due to the fact that on account of the complexity of modern political and economic dependencies, the United States has changed the priorities in its foreign policy. In the context of European partners, this means that London's close allies often include Berlin or Paris. On their part, Brits are not longer so eager to involve such forces and financial assets in various military operations as they used to in the past, simultaneously trying to develop economic and trade relations in other parts of the world (e.g. with China) which, in the course of time, may result in the weakening of the status of the "special relationship" in the British foreign policy ${ }^{29}$. On the other hand, voices are also heard that Great Britain and the United States will remain close allies as in numerous areas (e.g. military cooperation or intelligence sharing) their ties are exceptionally strong. In turn, this means that these countries will continue to cooperate closely - starting from trade cooperation, cooperation as part of NATO, up to facing various challenges related to security - both in the regional and global dimension ${ }^{30}$.

As far as relations between the current president of the United States, Donald Trump and the head of the British cabinet, Theresa May, are concerned, they seem to be positive, yet it is difficult to determine whether this is the result of courtesy resulting from the functions held by the politicians or whether there is really certain world-view communion between them. Trump enjoys positive opinions among other members of the British cabinet, e.g. Foreign Secretary Boris Johnson, who strongly believes in the durability of the British and American alliance and who suggested

\footnotetext{
28 K. Fox, Donald Trump and Theresa May: Another 'special relationship'?, CNN, 1 February 2017, http:// edition.cnn.com (retrieved: 22.04.2017).

29 M. Knigge, 'Special relationship' between Britain and US turns normal, Deutsche Welle, 8 March 2016, http://www.dw.com (retrieved: 22.04.2017).

30 D.E. Mix, The United Kingdom: Background and Relations with the United States, Congressional Research Service, Report RL33105, pp. 2-3.
} 
in one of his recent statements that if the United States asked Great Britain for assistance with the military intervention in Syria, "it would be difficult for us to say 'no'”31. This may mean that for Great Britain, which is on the verge of leaving the European Union, the "special relationship" with the United States is as important as it was when Winston Churchill used this term for the first time.

However, the question remains with respect to the less predictable of the two partners, i.e. Donald Trump. The evaluation of his activities by the British public opinion has not been best so far, and numerous of his statements have been in contrast with the values important for the British, irrespective of their political likings. It often turns out in Great Britain that a social dispute translates to political opposition. This was clearly evidenced by the unprecedented speech of the Speaker of the House of Commons - John Bercow, after Theresa May's return from the United States. Referring to the information that President Trump accepted the Queen's invitation to pay an official state visit to Great Britain this year, Bercow, who represented the Conservative Party prior to becoming the Speaker, announced to the members of the House of Commons that he does not agree for Trump to deliver a ceremonious speech before the combined houses of the British Parliament in the Westminster Palace. His arguments included a lack of acceptance for statements and first decisions of the US President - including the reference to his immigration policy. In this manner, Bercow expressed his deep conviction that "our opposition to racism and to sexism and our support for equality before the law and an independent judiciary are hugely important considerations in the House of Commons ${ }^{\prime \prime 2}$. The speech in the historic Westminster Hall is not a mandatory element of every state visit to Great Britain, but it is considered a great honour reserved exclusively for the most desired guests. In the last several decades, this honour was bestowed on John Paul II, Nelson Mandela and Barack Obama. Obama spoke as the leader of the free, democratic world, but also as the President of the United States tied by the "special relationship" with Great Britain. Failing to honour Trump in this manner would not only be a diplomatic gaffe, but also a serious crack in the "special relationship"; obviously not the first one, but very symbolic.

Despite so many challenges facing the British and American alliance, as well as numerous potential problems that the United Kingdom and the United States will have to deal with in the coming months, both in Washington and in London, there

\footnotetext{
31 Johnson: Difficult to say 'no' to Syria strike, BBC News, 27 April 2017, http://www.bbc.com/news/ (retrieved: 29.04.2017)

32 A. Asthana, J. Elgot, R. Mason, Donald Trump should not be allowed to speak in UK parliament, says Speaker, "The Guardian", 6 February 2017, https://www.theguardian.com (retrieved: 29.04.2017).
} 
is a conviction that the "special relationship" will endure. The only question is how effective it is going be.

\section{Bibliography}

Asthana A., Elgot J., Mason R., Donald Trump should not be allowed to speak in UK parliament, says Speaker, "The Guardian", 6 February 2017, https://www.theguardian.com (retrieved: 29.04.2017).

Asthana A., Mason R., Barack Obama: Brexit would put UK 'back of the queue' for trade talks, “The Guardian", 22 April 2016, https://www.theguardian.com (retrieved: 28.04.2017).

Bromund T.R., The Special Relationship: Anglo-U.S. Relations since 1776, "Oxford Research Encyclopaedia of American History”, Oxford University Press, USA 2016.

Buras P., Przygotujcie się na nowa Europę, Fundacja im. S. Batorego, Warszawa 2017.

Churchill W., The Sinews of Peace, https://www.winstonchurchill.org/resources/speeches/ 1946-1963-elder-statesman/the-sinews-of-peace (retrieved: 27.04.2017).

Crowley P.J., How Brexit will affect US-UK relations, BBC News, 26 June 2016, http://www. bbc.com/news/ (retrieved: 20.11.2017).

Danel Ł.,Demokracja brytyjska w obliczu Brexitu i ewentualnej dekompozycji Zjednoczonego Królestwa, [in:] Demokracja wspótczesna - wymiar polski i międzynarodowy, J. Kornaś, Ł. Danel (Eds.), Wydawnictwo Adam Marszałek, Toruń 2016.

David Cameron stands by attack on Donald Trump over Muslim 'ban', BBC News, 16 May 2016, http://www.bbc.com/news (retrieved: 28.04.2017).

Fox K., Donald Trump and Theresa May: Another 'special relationship'?, CNN, 1 February 2017, http://edition.cnn.com (retrieved: 22.04.2017).

Gogowski G., Znaczenie specjalnych stosunków ze Stanami Zjednoczonymi dla brytyjskiej polityki bezpieczeństwa po zakończeniu zimnej wojny, [in:] Nowe spojrzenia w naukach o polityce, W. Jakubowski, $\Lambda$. Krawczyk, J. Szczepański (Eds.), Wydawnictwo Uniwersytetu Warszawskiego, Warszawa 2012, vol 2.

Heywood A., Essentials of UK Politics, Palgrave Macmillan, Basingstoke-New York 2011. http://www.phrases.org.uk/meanings/special-relationship.html (retrieved: 27.04.2017).

John T., Theresa May and Donald Trump and 5 Other 'Special Relationships', "Time”, 26 January 2017, http://amp.timeinc.net/time (retrieved: 22.04.2017).

Johnson: Difficult to say 'no' to Syria strike, BBC News, 27 April 2017, http://www.bbc.com/ news/ (retrieved: 29.04.2017).

Knigge M., 'Special relationship' between Britain and US turns normal, Deutsche Welle, 8 March 2016, http://www.dw.com (retrieved: 22.04.2017). 
Larres K., Donald Trump and America's Grand Strategy: U.S. foreign policy towards Europe, Russia and China, "Global Policy", May 2017, http://www.globalpolicyjournal.com/ (retrieved: 12.10.2017).

Lowther W., Owen G., Secret US memo for Congress seen by Mail on Sunday says Britain's 'special relationship' with America is over, "Daily Mail", 12 April 2015, http://www.dailymail.co.uk/news (retrieved: 27.04.2017).

Mix D.E., The United Kingdom: Background and Relations with the United States, Congressional Research Service, Report RL33105.

Out and down. Mapping the impact of Brexit, The Economist Intelligence Unit, http://www. transatlanticbusiness.org/wp-content/uploads/2016/09/Out-and-Down-Mappingthe-Impact-of-Brexit-The-Economist-Intelligence-Unit.pdf (retrieved: 15.10.2017).

Sybilla Bidwell A., Dzieje Wielkiej Brytanii w XX wieku. Od światowego imperium do „małego państwa" na obrzeżach Europy, Wydawnictwo Szkoły Wyższej Psychologii Społecznej "Academica", Warszawa 2008, p. 189.

The economic consequences of leaving the EU. The final report of the CER commission on Brexit 2016, Centre for European Reform, April 2016, http://www.cer.eu/sites/default/ files/smc2016_26april2016.pdf (retrieved: 15.10.2017)

Warchał A., Zarys brytyjsko-amerykaniskiego partnerstwa politycznego, [in:] Era Blaira i Browna. Wybrane problemy polityczne rzadów Partii Pracy w Zjednoczonym Królestwie 1997-2010, P. Biskup, F. Golembski, M. Kaczorowska (Eds.), Oficyna Wydawnicza ASPRA-JR, Warsaw 2010.

What does Trump victory mean for UK-US 'special relationship'?, Reuters, 9 November 2016, https://www.rt.com/document (retrieved: 28.04.2017).

Wintour P., US seeking bilateral trade deal with UK to press EU on TTIP, "The Guardian", 20 July 2016, https://www.theguardian.com (retrieved: 15.11.2017).

\section{Special Relationship between the United Kingdom and the United States of America in the Light of Brexit and Donald Trump's Victory in the Presidential Election}

This article is devoted to the "special relationship" between the United Kingdom and the United States: a strategic partnership that has united these two countries for good after WWII, even though in many respects it has lasted since the first half of the $19^{\text {th }}$ century. The author starts with presenting the historic outline of the "special relationship" with an emphasis on the characteristics of mutual ties and dependencies. The author also analyses the political circumstances in which tightening or loosening of the British and American relations took place. In the 
final part of the article, the author refers to the most recent political events, which in 2016 took place in Great Britain and in the United Sates. In this manner, the author is trying to answer the question on how the decision on leaving the European Union by Great Britain (the so-called Brexit) and the election of Donald Trump as the US president will influence the shape of the British and American alliance.

Keywords: special relationship, United Kingdom, United States of America, Brexit, Trump

\section{La relation spéciale entre le Royaume-Uni et les États-Unis d'Amérique à la lumière du Brexit et la victoire de Donald Trump à lélection présidentielle}

Le texte est consacré aux «relations spéciales» entre le Royaume-Uni et les États-Unis - un partenariat stratégique qui a bien réuni les deux pays à la fin de la Seconde Guerre mondiale bien qu'à de nombreux égards, il dure depuis la première moitié du XIX ${ }^{e}$ siècle. L'auteur commence par la présentation d'un aperçu historique des «relations spéciales» avec un accent particulier mis sur les caractéristiques des liens mutuels et des dépendances. Il analyse également dans quelles circonstances politiques les relations anglo-américaines étaient renforcées et dans lesquelles elles étaient maîtrisées. Dans la dernière partie du texte, l'auteur fait référence aux événements politiques les plus récents qui ont eu lieu en 2016 en Grande-Bretagne et aux États-Unis. De cette façon, il tente de répondre à la question de savoir comment la décision de quitter l'Union européenne par le Royaume-Uni (le soi-disant Brexit) et l'élection du président américain Donald Trump affecteront la forme de l'alliance américano-britannique.

Mots-clés: relation spéciale, Royaume-Uni, États-Unis d’Amérique, Brexit, Trump 


\section{Особые отношения между Соединенным Королевством и Соединенными Штатами Америки в контексте Брексита и победы Дональда Трампа на президентских выборах}

Статья посвящена «особым отношениям» между Соединенным Королевством и Соединеншыми Штатами - стратегическому партнерству, которое объединило эти две страны после Второй мировой войны, хотя во многих отношениях оно продолжалось с первой половины ХІХ века.

Автор начинает с исторического очерка «особых отношений», уделяя внимание характеристике их взаимоотношений. Анализу подвергапося политические обстоятельства, в которых имело место укрепление или ослабление британско-американских отношений.

В заключительной части статьи автор относится к последним политическим событиям 2016 г. в Великобритании и в Соединенных Штатах, таким образом пытаясь ответить на вопрос о том, как решение Великобритании покинуть Европейский Союз (т.н. «Брексит») и выборы президента СIIА Дональда Трампа повлияго па британско-американский альянс.

Ключевые слова: особые отношения, Соединенное Королевство, Соединенпые Штаты Америки, Брексит, Трамп 